\title{
nature
}

\section{When payment by results is a sensible approach}

A proposal that senior German academics be paid on the basis of job performance has raised a storm of protest. But that should not obscure the value of this - and other - proposals for university reform.

T here is nothing like an attack on the pocket to bring people out in protest. Thus an army of German university professors is now rallying against a recommendation by the University Rectors Conference (HRK) that their pay should in future depend on research and teaching performance, rather than their length of service and number of family dependants (see page 396).

The negative reaction is unsurprising, given that the recommendation would mean lower salaries for the mediocre. But a number of remarkable reasons have been put forward in the past couple of weeks to defend the traditional fixed-salary structure - even to the extent of calling as witness the constitutional right of scientific freedom. To summarize these crudely: if professors are distracted by worries about whether they will qualify for a pay increment, they will not be psychologically free to carry out their research effectively.

Such a conservative response does not serve the research community well. Academics and their universities form part of a world that increasingly demands accountability from those who are paid from the public purse. If the universities are to retain public support, they must ensure that such accountability has teeth. At present, a German professor reigns more or less unchallenged in his (rarely her) kingdom. He will receive some research money from his university, whether or not impartial experts judge his research to be worthwhile. This has not, of course, stopped the more talented self-starters from achieving research excellence - as plenty of German Nobel prizewinners demonstrate. But it has probably prevented the less talented and selfmotivated from reaching a higher level of achievement than they do.

Politicians, backed by a small number of relatively enlightened academics, have campaigned for years, against a groundswell of resistance, to change the federal 'framework' law on Germany's regionally funded universities. Such changes now give the universities, among other things, the budgetary independence that allows them to allocate more research money to higher achievers. But increasing salaries for high achievers would require another change in federal law, in order to release academic staff from the public-servant salary scales set by the federal government. The HRK cannot influence this situation directly. But hopefully the debate that it has opened up will help persuade politicians to take the next logical step to their successful modifications to the framework law.

Sadly, the issue of pay was the only one of a set of sensible efficiencyraising recommendations put forward by the HRK to have received significant attention from the grassroots academic community. In particular, the rectors' call for universities to abandon Habilitation, a postdoctoral qualification traditionally required to join professorial ranks, was greeted with a resounding silence.

The HRK's call for its abandonment is only the latest in a long succession of such calls; but is no less correct for that. Hundreds of young researchers are asked to spend valuable time 'proving' through research experience in their professor's laboratory, through the writing of a further thesis and through years of supporting their professor's teaching activities, that they are suitable for consideration as professors in German universities. This method serves only to extend training time, usually until at least the age of 40; a bundle of key research papers and standard evidence of teaching experience would suffice just as well as proof of worthiness, as it does in other countries.

Any proposal by a group of employers whose effect would be to reduce the living standards of some of their employees — even though these will remain relatively high - deserves tough scrutiny. But the rectors' recommendations need to be addressed in a positive spirit if Germany's universities are to remain internationally competitive, and thus worthy of support from the German taxpayer.

\section{Will we see their like again?}

\section{Departing directors at the top US physics laboratories leave a discipline in search of inspired leadership.}

W

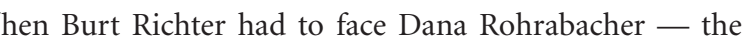
abrasively right-wing congressman who had just taken on the chair of an influential committee with oversight of scientific programmes at the US Department of Energy — he found a quick way to connect with a politician more naturally at home with the National Rifle Association than with the American Physical Society, of which Richter happened to be president at the time. Richter invited Rohrabacher round to try out his pistol collection. "I wanted him to know that not all physicists are wimps," he later explained.

Such resourcefulness will be sorely missed when Richter steps down next August as director of the Stanford Linear Accelerator Center in California (see page 397). Indeed, the exit of the Nobelprizewinning physicist will leave many scientists at the Department of Energy laboratories wondering where they will see his like again. For coming on top of last year's unfortunate departure of Nick
Samios (another blunt New Yorker) from the Brookhaven National Laboratory, New York, and next year's retirement of John Peoples from Fermilab in Illinois, Richter's departure leaves the US highenergy physics community grappling for fresh leadership at a time when its political support is far from assured.

It would be short-sighted to observe the stature of these men and conclude them to be irreplaceable. Each in turn, after all, stepped comfortably enough into the shoes of a previous generation of physicists that had lifted its immense national prestige directly from its role in the Manhattan project. But these days, it is only the weapons laboratories at Los Alamos, Sandia and Livermore that retain such prestige and the funding that accompanies it. The non-weapons laboratories stand alone, and relatively exposed. A new generation of leaders is now sorely needed to win friends, influence people and lead US particle physics into the twenty-first century. 